\title{
MECHATRONIKA KÉPZÉS AZ ÓBUDAI EGYETEM BÁNKI KARÁN
}

\section{THE MECHATRONIC EDUCATION AT THE BÁNKI FACULTY OF ÓBUDA UNIVERSITY}

\author{
Nagy István ${ }^{1}$, Langer Ingrid ${ }^{2}$, Rácz Pál ${ }^{3}$ \\ ${ }^{1,2}$ Óbudai Egyetem Bánki Donát Gépész és Biztonságtechnikai Mérnöki Kar, \\ Mechatronikai és Jármütechnikai Intézet, 1081, Magyarország, Budapest, \\ Népszínház u. 8. Telefon: +361666-5366 \\ Inagy.istvan@bgk.uni-obuda.hu \\ 2langer.ingrid@bgk.uni-obuda.hu \\ ${ }^{3}$ Bay Zoltán Alkalmazott Kutatási Közhasznú Nonprofit Kft., H-1116 Budapest, \\ Kondorfa u. 1., Tel./Fax.: 36-1-463-0569,pal.racz@bayzoltan.hu,www.bayzoltan.hu
}

\begin{abstract}
The predecessor of Óbuda University, -Budapest Tech-, first introduced its bachelor's level "mechatronics engineer" course in September 2005. As an opportunity for full academic education, in September 2009 we started the mechatronics engineering on master's level, too, however only on parttime course. In year 2011 the English Mechatronic Course has been launched on BSc level, and later in 2015 on MSc level. These new conditions motivated the institute constantly renew its mechatronic teaching plan. In this paper the history of formation of "Institute of Mechatronics and Vehicle Engineering" as well as the developing of the Mechatronics Teaching Plans will be introduced.
\end{abstract}

Keywords: Mechatronic, Teaching Plan, Credits, Ministry of Human Resources (MHR),

\section{Összefoglalás}

Az Óbudai Egyetem jogelődje, a Budapesti Müszaki Főiskola 2005 szeptemberében indította el a Mechatronikai mérnök alapképzését. A teljes egyetemi képzést lehetővé téve 2009 szeptemberétől esti tagozat keretében elindult a mesterszak is. 2011-től bevezetésre került az angol nyelvü Mechatronikai mérnök BSc, majd 2015-től az MSc képzés. Ezek a változások késztették a Mechatronikai és Jármütechnikai Intézetet a Mechatronikai mérnök képzés tantervének megújítására. Az alábbiakban bemutatjuk a Mechatronikai mérnök képzés történetét valamint a tantervfejlesztés folyamatát.

Kulcsszavak: mechatronika, tanterv, kredit, Emberi Eröforrások Minisztériuma (EMMI)

\section{Bevezetés}

A magyar ipar a rendszerváltást követő recesszió után a 2000-es években dinamikus fejlődésnek indult. Ennek meghatározó tényezője az export növekedése volt, ami elsősorban a hazai beszállítókkal együttmüködő modern mechatronikai technológiát alkalmazó multinacionális vállalatoknak köszönhető.
Ennek a fejlődésnek a fenntartásához hozzáértő mérnökök szükségesek, akik jártasak a modern tervezésben, ismerik a technológiai és üzemeltetési módszereket, és ezeket képesek alkalmazni a gyakorlatban. Ezen társadalmi igények kielégítésére az Óbudai Egyetem jogelőd intézménye, a Budapesti Müszaki Főiskola úgy döntött, hogy elindítja a Mechatronikai mérnök alapképzést. [1]. 


\subsection{A Mechatronikai mérnök képzés létrehozásának története}

A mechatronika tantárgyként való oktatása még a Bánki Donát Gépipari Müszaki Főiskolán kezdődött a 90-es évek elején. A Bánki 2000-ben a felsőoktatási integrációs folyamat keretén belül a Kandó Kálmán Villamosipari Müszaki Főiskolával és a Könnyüipari Müszaki Főiskolával Budapesti Műszaki Főiskola néven egyesült, majd az egyetemi státusz elnyerése után 2010 óta az Óbudai Egyetem karaként müködik. A „Mechatronika alapjai" tárgy a gépészmérnök-képzésben az óta is szerepel.

A bolognai folyamat részeként 2005 szeptemberétől a magyar felsőoktatásban is bevezetésre került a kétszintü képzés. Ezzel egy időben indult a Bánki karon a magyar nyelvü Mechatronikai mérnök BSc, majd 2009-ben az MSc képzés. 2011/12-es tanévtől kezdve bevezetésre került az angol nyelvü Mechatronikai mérnök BSc, majd 2015-től az MSc képzés. Ebben az időben a mechatronikai mérnök képzésre következő irányelveket határozták meg: A BSc szintü végzettséggel rendelkező mechatronikai mérnök képes létrehozni mechatronikai berendezéseket, valamint képes ezek telepítésére, üzemeltetésére, karbantartására és ellenőrzésére. Az MSc szintü végzettséggel rendelkezők képesek kutatási és fejlesztési feladatok ellátására is. Napjainkban az oktatásért felelős minisztérium szintén irányelvek formájában határozza meg a követelményeit.

\section{Tantervfejlesztés}

A jelenlegi tantervfejlesztés irányelveit az Emberi Erőforrások Minisztériuma (EMMI) és ezen belül az Oktatásért Felelős Államtitkárság határozta meg. Az általuk kiadott irányelvek, ún. „KKK” (Képzési és Kimeneti Követelmények) tartalmazzák a szakindítással kapcsolatos általános jellemzőket (pl. képzettségi szint, attitűdök, képességek, autonómia és felelősség, kredit értékek, szakmai gyakorlatok feltételei, stb..) és a különböző végzettségek kompetenciáit. Ezeket hívjuk általánosan egy adott szakma „képzési és kimeneti követelményei"'-nek. A Mechatronikai képzés BSc és MSc szintjére vonatkozóan a minisztériumi irányelvek a következőket határozzák meg:

- az alap/mester képzési szak megnevezése

(mechatronikai mérnöki);

- szakképzettség (mechatronikai mérnök);

- végzettségi szint (alap (BSc) / mester

(MSc) fokozat)

- képzési terület (müszaki)

- képzés hossza (BSc 7 félév / MSc 4 félév)

- az oklevél megszerzéséhez

összegyüjtendő kreditek száma (BSc 210 /

MSc 120 kredit)

- a képzés célja

- elsajátítandó szakmai kompetenciák

- egyéb jellemzők

\subsection{A Mechatronikai mérnök-képzés általános jellemzői}

A képzés alapvető jellemzőinek kidolgozása az EMMI által kiadott irányelvek alapján történt, melyben meghatározták a szakképzettséghez vezető tudomány-ágakat és szakterületeket, amelyekből a szak felépül. Lásd. 1. táblázat.

1. táblázat. A Mechatronika képzés képzési területeinek ajánlott kreditértékei

\begin{tabular}{|l|l|l|}
\hline & Alapképzés & Mesterképzés \\
\hline $\begin{array}{l}\text { Természettudomán } \\
\text { yos ismeretek }\end{array}$ & $\begin{array}{l}40-50 \\
\text { kredit }\end{array}$ & $20-35$ kredit \\
\hline $\begin{array}{l}\text { Gazdasági és } \\
\text { humán ismeretek }\end{array}$ & $\begin{array}{l}14-30 \\
\text { kredit }\end{array}$ & $10-20$ kredit \\
\hline $\begin{array}{l}\text { Mechatronikai } \\
\text { mérnöki szakmai } \\
\text { törzsanyag }\end{array}$ & $\begin{array}{l}70-105 \\
\text { kredit }\end{array}$ & $15-35$ kredit \\
\hline $\begin{array}{l}\text { Választható } \\
\text { specializáción } \\
\text { szerezhetö } \\
\text { ismeretek }\end{array}$ & $\begin{array}{l}\text { min 40 } \\
\text { kredit }\end{array}$ & $\begin{array}{l}40-60 \text { kredit (a } \\
\text { diplomamunká- } \\
\text { val együtt) }\end{array}$ \\
\hline
\end{tabular}


A táblázat utolsó sorában az ún. specializáció azt jelenti, hogy minden mechatronikai képzést folytató intézménynek biztosítania kell különféle szakirányokat, mint pl. bio-mechatronika, opto-mechatronika, jármümechatronika, épületmechatronika, ... stb.

Az Óbudai Egyetem az alapképzésben (BSc) egy (Ipari robotrendszerek), mesterképzésben (MSc) két specializációt (Jármüinformatika valamint Intelligens robotrendszerek mechatronikája) biztosít.

\subsection{A Mechatronikai mérnök képzés jellemzői az óbudai Egyetem Bánki Donát karán}

Az EMMI irányelveiből kiindulva a magyar müszaki felsőoktatásban a tanterv négy tudományterületet ölel fel: természettudományok, humán és gazdasági ismeretek, szakmai törzsanyag és speciális szakmai ismeretek. Az 1. táblázatban megjelölt kreditértékeknek megfelelően az Óbudai Egyetemen a valóságban elért négy tudományterület arányai és kreditértékei is láthatók az egyes tudományterületeknek megfelelően, lásd, zárójelben dőlt betük.

A mechatronikai képzésnek, a mechatronika alapdefiníciójából kiindulva, három müszaki tudományterületet, a gépészetet, az elektronikát és az informatikát kell összeintegrálnia, ezért az Óbudai Egyetemen a Mechatronikai mérnökképzés három kar közremüködésével történik:

-Bánki Donát Gépész és Biztonságtechnikai Mérnöki Kar

- Kandó Kálmán Villamosmérnöki Kar

- Neumann János Informatikai Kar

A magas oktatási színvonal elérése érdekében a szakmai tárgyak oktatása e karok között a tantárgyaknak megfelelően megosztva történik.

\subsection{A tantervfejlesztés megvalósítása}

A tantervfejlesztés során nem csak a minisztérium irányelveit, hanem az Óbudai
Egyetem által meghatározott elöirányzatokat is figyelembe kellett venni. Ezek biztosították, hogy a hallgatók tanulmányi terhelése a képzés során kiegyensúlyozott legyen. Továbbá számításba kellett venni az oktatói kapacitást is, mind a magyar, mind az angol nyelvü képzésen valamint a rendelkezésre álló laboratóriumi infrastruktúrát. a kialakított tantárgyi struktúra a 2. és 3. táblázatban látható

2. táblázat. Az alapképzés tantárgyai

\begin{tabular}{|c|c|}
\hline \multicolumn{2}{|c|}{ Alapképzés - Ipari robotrendszerek } \\
\hline $\begin{array}{l}\text { Természet- } \\
\text { tudományos } \\
\text { tárgyak }\end{array}$ & $\begin{array}{l}\text { Matematika } 1,2 ; \text { Mérnöki fizika; } \\
\text { Bevezetés a mechatronikába; } \\
\text { Mechanika 1,2,3 Elektrotechnika; } \\
\text { Mérnöki } \\
\text { Anyagtechnológia alapjai }\end{array}$ \\
\hline $\begin{array}{l}\text { Humán és } \\
\text { gazdasági } \\
\text { tárgyak }\end{array}$ & $\begin{array}{lr}\text { Makro- és mikroökonómia; Üzleti } \\
\text { gazdaságtan } & 1,2 ; \\
\text { Minőségbiztositás; } & \text { Jogi } \\
\text { ismeretek; Menedzsment } & \\
\end{array}$ \\
\hline $\begin{array}{l}\text { Szakmai } \\
\text { törzsanyag }\end{array}$ & $\begin{array}{lr}\text { Informatika } & 1,2, \\
\text { Gépszerkezettan; Elektromos } \\
\text { gépek és hajtások; CAD } \\
\text { rendszerek; Anyagtechnológia; } \\
\text { Rendszertan; Irányítástechnika; } \\
\text { Programnyelvek> Digitális } \\
\text { technika; Pneumatika és } \\
\text { hidraulika; PLC ismeretek; } \\
\text { Gyártástechnológia; Elektronika; } \\
\text { Müszertechnika; Interfészek; }\end{array}$ \\
\hline $\begin{array}{l}\text { Specializáció } \\
\text { (Ipari } \\
\text { robotrend- } \\
\text { szerek) }\end{array}$ & $\begin{array}{l}\text { Ipari robotok programozása és } \\
\text { szimulációja; Robotizálás és } \\
\text { gyártásautomatizálás; Ipari } \\
\text { robotok kinematikája és } \\
\text { dinamikája; Jármű mechatronika; } \\
\text { CAD tervezés; IT hálózatok; } \\
\text { Projekt munka; Szakdolgozat; }\end{array}$ \\
\hline
\end{tabular}

\section{Következtetések}

A 2. és 3 táblázatban látszik, hogy a mesterképzés tárgyai az alapképzés tárgyain alapulnak. A mesterképzés az alapképzéshez képest specifikusabb, egzaktabb tudásanyagot biztosít és szélesíti a hallgatók tudományos látószögét. 
Ha összehasonlítjuk minisztérium által megadott kreditszámokat a megvalósított tanterv kreditszámaival a három különböző tudományterületen (1. táblázat első 3 sor), látható, hogy a létrejött tanterv jól illeszkedik a kijelölt előirányzathoz, lásd

\section{1. ábra.}

3. táblázat. A mesterképzés tantárgyai

\begin{tabular}{|c|c|}
\hline \multicolumn{2}{|c|}{$\begin{array}{l}\text { Mesterképzés - Jármüinformatika / Intelligens } \\
\text { robotrendszerek mechatronikája }\end{array}$} \\
\hline $\begin{array}{l}\text { Természet- } \\
\text { tudományos } \\
\text { tárgyak }\end{array}$ & $\begin{array}{l}\text { Optimum számítási eljárások; } \\
\text { Mérnöki fizika; A mechatronika } \\
\text { válogatott fejezetei; } \\
\text { Villamosságtan; A hő- és } \\
\text { áramlástan válogatott fejezetei; } \\
\text { Anyagtudomány }\end{array}$ \\
\hline $\begin{array}{l}\text { Humán és } \\
\text { gazdasági } \\
\text { tárgyak }\end{array}$ & $\begin{array}{l}\text { Üzleti gazdaságtan; Mérnöki } \\
\text { menedzsment }\end{array}$ \\
\hline $\begin{array}{l}\text { Szakmai } \\
\text { törzsanyag }\end{array}$ & $\begin{array}{l}\text { Beágyazott rendszerek; Mikro- } \\
\text { és nanotechnológia; Müszaki } \\
\text { optika; Modellezés és } \\
\text { szimuláció; Mechatronikai } \\
\text { szerkezetek; Szenzorok és } \\
\text { jelanalízis; Intelligens mérnöki } \\
\text { rendszerek; CAD rendszerek; } \\
\text { Fuzzy rendszerek; } \\
\text { Önszerveződő rendszerek }\end{array}$ \\
\hline $\begin{array}{l}\text { Specializáció } \\
\text { (Jármü } \\
\text { informatika) }\end{array}$ & $\begin{array}{l}\text { Járművek informatikai } \\
\text { rendszerei; Járműdinamika; } \\
\text { Járműelektronika; Közlekedési } \\
\text { információ technológia; Multi- } \\
\text { ágensü mobilrobot rendszerek; } \\
\text { Mechatronikai rendszerek } \\
\text { megbízhatósága }\end{array}$ \\
\hline $\begin{array}{l}\text { Specializáció } \\
\text { (Intelligens } \\
\text { robot- } \\
\text { rendszerek } \\
\text { mechatronikáj }\end{array}$ & $\begin{array}{l}\text { Intelligens rendszerek; Multi- } \\
\text { ágensü mobilrobot rendszerek; } \\
\text { Modern gyártási technológiák, } \\
\text { Adaptív szabályozórendszerek }\end{array}$ \\
\hline
\end{tabular}

Végezetül, a kiegyensúlyozott elméleti és gyakorlati képzés arányára is adott ki a minisztérium egy ajánlatot, 60\% - 40\%-os, elmélet - gyakorlat eloszlást ajánl.
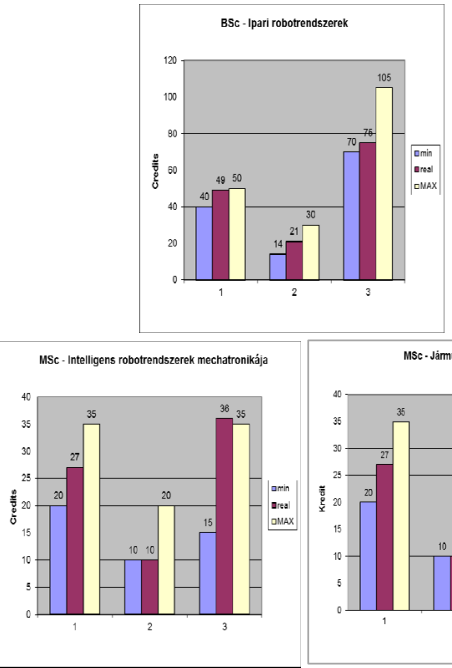

1. ábra. A tantervben megvalósitott valós kreditszámok (középsö oszlopok) az EMMI által meghatározott min.-max. értékekhez képest a három tudományterületen

\section{Szakirodalmi hivatkozások}

[1] I. Nagy, A.L. Bencsik: Complex System Development for Mechatronic Education, Proceedings of 14th Mechatronics Forum International Conference, Mechatronic 2014, ISBN 978-91-7063-564-9, Published by Karlstad University, Sweden, 2014, pp.: 362370.

[2] http://www.banki.hu/indexeng.php?sid=kare ng\&pid=tortenelmunk

[3] Emberi erőforrások minisztere: Elöterjesztés a felsőoktatási szakképzések, az alap- és mesterképzések képzési és kimeneti követelményeiröl, 2011. évi CXII. törvény 27. $\S(5)-(7)$ bekezdés.

[4] I. Nagy, A.L. Bencsik: Mechatronics at the Bánki Polytechnic (15 years in research and Education),1st International Symposium on Mechatronics, Budapest, 2001.

[5] I. Nagy, A.L. Bencsik: Mechatronics: A New Very Promising Engineering and Science Discipline, EADS Engineering Europe, Symposium, Programfüzet, (+CD), ISBN 978-963-7154-75-1, Budapest, 2008. 